\title{
ANALISIS FIQH FIQH KOTEMPORER TERHADAP "NYANDAK” MASYARAKAT SASAK
}

\section{MUSAWAR}

Dekan Fakultas Syariah Universitas Islam Negeri Mataram

Email: musawwar_1@yahoo.com

\begin{abstract}
Abstrak
Artikel ini membahas tentang "Sandak" yaitu salah satu bentuk muamalah yang lazim dikenal di kalangan masyarakat Sasak. Sandak merupakan bentuk transaksi yang bernilai ekonomiskomersial dalam upaya pemanfaatan lahan pertanian. Tidak ada padanan istilah yang fixed bagi Sandak dalam disiplin ilmu fiqh. Ada yang menyebutnya sebagai "pinjam uang pinjam tanah", "jual beli sementara", dan bahkan ada yang menyebutnya sebagai bentuk lain dari gadai.Sebenarnya tradisi Sandak bisa diklasifikasikan sebagai salah satu modus operandi praktek muamalah pada umunya, seperti jual beli, sewa-menyewa, pinjam meminjam, muzarah dan lain sebagainya. Namun, bila praktek sandak tersebut dibedah secara detail dengan teori al-Rahn (gadai), al-Qardh (pinjam meminjam), dan al-Riba dalam perspektf madzhab fiqh, maka akan ditemukan unsur-unsur yang kontroversial dan dilarang. Padahal muslim Sasak secara mayoritas adalah penganut setia madzhab Syafi'i. Di sinilah menariknya masalah ini untuk dikaji. Dalam penelitian ini, ditemukan bahwa masyarakat Sasak telah secara sadar atau tidak mengadopsi sistem bermadzhab secara eklektif (takhayyur). Mereka lebih memilih berlindung di balik pandangan madzhab Hanafi yang dirasa lebih akomodatif terhadap praktek Sandak. Dalam hal ini, ada dua model transaksi untuk melegalkan praktek sandak. Pertama, masyarakat mengambil opsi transaksi "permohonan izin dalam penggarapan sawah" sebagai bentuk aqad sandak yang diakui oleh mazhab Hanafi. Sementara cara yang lain adalah apa yang disebut dengan "Ba'y al-Wafa" yaitu satu bentuk transaksi dalam rangka memenuhi hajat, dengan alasan "al-hajat tanzîl manzila al-dlarura ‘âmmah wa khâshshah”.
\end{abstract}

Kata Kunci: Sandak, al-Rahn, al-Qardl, al-Riba, ba’y al-Wafa', Hilah

\begin{abstract}
This article aims to discuss "Sandak" as a kind of economic practice among the Sasakness people. The term Sandak is a form of transaction, having commercial and economic value within the Sasakness community especially in the area of farming. There is no exact equivalent for the term Sandak in Islamic Law (fiqh). But it is known as "pinjam uang pinjam sawah" or "jual beli sementara" and it is assumed as a part of mortgage. Commonly, Sandak in the tradition of Sasakness community is a part of contract, like a selling, renting, loan and etc. When Sandak is investigated carefully thorough Islamic Law theory, al-Rahn (mortgage), al-Qardl (loan) and al-Riba (usury) in the perspective Islamic scholars, it is found that some aspects are debatable and forbidden, whereas the majority of Sasakness community believe in Syafi'i ideas. This point becomes interesting to study. On the other hand, the majority of Sasakness community, known or unknown, have followed Hanafis scholars. They prefer to choose Hanafis scholars that are believed to be accommodative to legalize the Sandak practice. Regarding this view, the Sandak is usually practiced with two models: the first, Sandak is practiced with permission to use the rice field or garden as contract that claimed by Hanafis ideas. The second is the "Ba'y al-Wafa' concept to fulfill the
\end{abstract}


needs of them with this argumentation "al-hajat tanzîl manzila al-dlarura 'âmmah wa khâshshah"

Keywords: Sandak, al-Rahn, al-Qardl, al-Riba, ba'y al-Wafa', Hilah

\section{Pendahuluan}

Salah satu dari khazanah kebudayaan masyarakat Sasak Lombok adalah praktek Sandak. ${ }^{1}$ Bentuk tradisi lain yang khas dari masyarakat Sasak adalah ${ }^{2}$ belangar, $^{3}$ betulung, $^{4}$ gotong royong, banjar, benjango, ${ }^{6}$ ngayo, dan merang (perang). Sandak yang menjadi budaya masyarakat Sasak adalah salah satu bentuk muamalah dalam bidang pertanian atau perkebunan atau lainnya. Cara ini ditempuh sebagai salah satu jalan keluar dari kesulitan ekonomi.

Kesulitan ini dapat diilustrasikan dengan contoh bahwa ketika seorang yang mengalami kesulitan keuangan, ia segera mencari orang yang memiliki uang dengan membawa selembar photo copy sertifikat tanah atau kebun dengan tujuan sebagai jaminan uang yang akan dipinjamnya. Kemudian disambut oleh orang yang memberi pinjaman dengan catatan bahwa sawah atau kebun yang menjadi jaminan dapat digarap oleh yang meminjami uang selama pinjaman masih ada atau belum dikembalikan. Cara yang demikian itu dinamakan Sandak. ${ }^{8}$ Dari ilustrasi di atas dapat dirumuskan definisi Sandak, yaitu "pinjaman sejumlah uang oleh seorang dari orang lain, dengan pemberian jaminan berupa sawah atau kebun yang diberikan kepada pemberi pinjaman untuk digarap selama pinjaman masih berada pada peminjam”. Dari pengertian ini dapat ditegaskan beberapa unsur dalam Sandak, yaitu: a). Unsur peminjaman yang mengambil manfaat dari peminjaman. ${ }^{9}$ b).Unsur gadai dengan jaminan yang diambil manfaatnya. ${ }^{10}$ c).Unsur jual beli yang disebut dengan "jual beli sementara"." Kalau dilihat dari unsur-unsur di atas, maka penggarapan sawah bagi pemberi pinjaman

\footnotetext{
${ }^{1}$ Kata "Sandak" adalah bahasa Sasak yang dalam bahasa Indonesia dapat diartikan dengan kata "menyandara" (menahan). Contoh, seseorang yang kehilangan seekor sapi kemudian sapinya ditahan oleh orang lain untuk minta tebusan.

${ }^{2}$ Asnawi, "Solidaritas Sosial Masyarakat dalam Pembangunan (Suatu Kajian Sosial Kultural Religius Pada Masyarakat Sasak)", laporan penelitian (tidak diterbitkan, STAIN Mataram, 1997), 1-5.

${ }^{3}$ Belangar adalah sama dengan melayat dimana para ibu-ibu datang membawa beras kepada keluarga yang meningggal.

${ }^{4}$ Betulung adalah sama dengan gotong royong yang lebih bersifat pertolongan tanpa pamrih dalam mengerjakan suatu perkerjaan, seperti membuat dasar rumah, resepsi, membuat masjid dan lainnya.

${ }^{5}$ Kegiatan semacam arisan dengan skop yang lebih luas, seperti arisan, kawin dan lainnya.

${ }^{6}$ Menjengo orang sakit atau menjengok orang tua oleh penganten baru.

${ }^{7}$ Mengunjungi tetangga atau bermain-main ke rumah teman.

${ }^{8}$ Observasi awal, tgl. 12-12-2009.

${ }^{9}$ Seperti yang dijelaskan oleh Rauhun (penggarap kebun). Wawancara tgl. 27- Juni 2010.

${ }^{10}$ Cara dengan gadai seperti dijelaskan oleh Mursal (petani). Wawancara $\operatorname{tgl}$ 22-Juni 2010.

${ }^{11}$ Cara seperti yang dijelaskan oleh Saharuddin (petani). Wawancara tgl, 24 Juni 2010
} 
merupakan keuntungan besar yang diperolehnya, karena selama uang (pinjaman) masih berada pada tangan peminjam, penggarapan sawah tetap dilakukan oleh pemberi pinjaman. Sementara peminjam hanya menunggu sawah akan kembali sampai ia dapat mengembalikan pinjaman, bahkan dapat terjadi pengalihan kepemilikan dengan pembayaran sedikit-sedikit sampai akhirnya dijual kepada pemberi pinjaman. ${ }^{12}$

Kemudian bagaimana bila dikaitkan dengan hukum Islam dengan berbagai teori fiqh yang ada dan adakah kemungkinan terjadinya peyimpangan dalam prtaktek Sandak menurut hukum Islam, sebab pendekatan yang diutamakan dalam penerapan muamalah adalah rasa keadilan dan menghindari riba. ${ }^{13}$ Oleh karena itu tidak dibolehkan adanya sistem riba, gharar, dzalim dan lainnya yang bersifat merugikan. ${ }^{14}$ Salain itu al-Qur'an melarang memakan harta sesama dengan jalan batal (tidak sah). Apakah praktek Sandak termasuk dalam kategori jalan yang batal, sesuai dengan firman Allah dalam Qs. Al-Nisa': 29.

Berangkat dari latar inilah, maka perlu dilakukan penelitian untuk memahami praktek Sandak dalam perspektif Hukum Islam. Selanjtanya dapat dirumuskan rumusan masalah sebagai fokus kajian yaitu: Mengapa masyarakat Sasak melakukan Sandak? Bagaimana status hukum implikasi Sandak dalam perspektif hukum Islam? Dua fokus kajian itu menjadi kajian dengan melihat kerangka teori yang ada dalam fiqh.

Dalam ilmu fiqh dikenal ada beberapa teori yang dibolehkan untuk melakukan transaksi; diantaranya adalah al-Qardh (pinjam meminjam). ${ }^{15}$ Prinsip al-Qardh adalah tolong menolong. Dalam tolong menolong itu tidak dibolehkan menarik keuntungan dari peminjaman tersebut, karena dapat merugikan orang lain, sesuai dengan ungkapan berikut: “Qullu Qardhin Jarra Manfaatan Fahuwa Riba” ${ }^{16}$ Dari itu setiap pemberian pinjaman yang menghasilkan keuntungan yang kembali kepada pemberi pinjaman dikatakan ribâ.

Selain teori al-Qardh, ada juga teori lain yang disebut dengan al-Rahn (jaminan). Fungsi dari al-Rahn ini adalah sebagai penguat atas pinjaman yang diberikan. Dasar hukumnya adalah al-Qur'an. ${ }^{17}$ Dari fungsi sebagai jaminan terhadap utang, maka menurut

\footnotetext{
${ }^{12}$ Wawancara dengan Rirqan dan Kharunniyah, tgl, 04 Junii -2010

${ }^{13}$ Najtullah Siddiqi, Kemitraan Usaha dan Bagi Hasil dalam Hukum Islam (Jakarta: Dana Bhakti Prima Yasam tt), 1.

${ }^{14}$ Ibid.

${ }^{15}$ lihat al-Qur'an Surat al- $\underline{\text { Hadîd }}$ (57): 11 .

${ }^{16}$ Oleh Imam Nawawi dalam Syarah Majmu' al-Muhadzdzab dianggap sebagai hadis yang melarang untuk melakukan transaksi al-qardl yang mengandung syarat yang menguntungkan. Lihat an-Nawawi, alMajmu' Syarh al-Muhadzdzab (Bairut: Dâr al-Fikr), jld xiii, 170. Sementara Sayyid Sabiq menjelaskan bahwa ungkapan di atas adalah merupakan qa'idah fiqhiyah yang sesuai dengan syara'. Lihat Sayyid Sabiq, Fiqh al-Sunnah (Beirut: Dâr al-Kutub al-Arabiy, 1985), jld iii, 163.

${ }^{17}$ Lihat al-Qur'an Surat al-Baqarah (2): 283.
} 
yang diformalisasikan ulama bahwa jaminan itu tidak boleh digunakan oleh penerima gadai (al-murtahin), karena ia hanya merupakan taustîq (penguat) atas hutang. ${ }^{18}$ Imam syafi’i menyatakan bahwa barang gadai tidak boleh dipergunakan oleh murtahin, tetapi ia hanya berhak menerima jaminan itu saja. ${ }^{19}$ Lebih lanjut Imam Nawawi menjelaskan bahwa almurtahin tidak memiliki hak dalam barang gadaian kecuali hanya memegang jaminan saja. ${ }^{20}$ Ulama Malikiyah juga menjelaskan bahwa penerima gadai hanya berhak menerima barang gadaian saja, ia tidak dibolehkan menerima barang gadaian. ${ }^{21}$

Selain dua teori di atas ada juga teori lain, yaitu "ba’i al-wafa” yaitu jual beli yang bersifat menggantung. Diberikan definisi oleh ulama' dengan pengertian berikut: “Bai' alwafá adalah jual-beli yang bersyarat bahwa kapan saja penjual dapat mengembalikan harga penjualan, maka pembeli dapat mengembalikan barang yang dibeli penjual." ${ }^{22}$ Definisi yang tidak jauh berbeda dengan ungkapan di atas, yaitu: "Ba’i al-wafa' adalah pernyataan penjual kepada pembeli: "Sebagai bandingan atas hutang Anda kepada saya, maka kapan saja Anda dapat membayar hutang Anda, maka hasil dari barang ini adalah miliki saya.” ${ }^{23}$ Dalam teori di atas dijelaskan bahwa penjual ini disebut dengan al-murtahin (penerima gadai), dan pembeli adalah al-rahin (pemberi gadai). Penggarapan sawah yang merupakan jaminan adalah bandingan atas hutang yang dipinjamkan kepada peminjam.

Jadi, ketiga teori ini dijadikan sebagai pisau bedah atau alat analisa terhadap praktek Sandak yang dilakukan masyarakat Sasak dalam rangka transaksi untuk memenuhi kebutuhan baik produktif atau pun konsumtif.

\section{Metode Penelitian}

Jenis penelitian ini adalah termasuk jenis penelitian lapangan (field research) yaitu prosedur penelitian yang menghasilkan data deskriptif berupa tulisan atau lisan dari orangorang dan perilaku yang diamati. ${ }^{24}$ Dengan lain kata penelitian ini merupakan penelitian intensif, terperinci dan mendalam terhadap suatu obyek tertentu dengan mempelajarinya

\footnotetext{
18al-Jashashah, Ahkâm al-Qur'ân (Beirut: Dâr al-Fikr, 1993), jld II: 724.

${ }^{19}$ al-Muzanniy, Mukhtashar al-Muzanniy ala al-Imâm Muhammad bin Idrîs al-Syâfi 'iy (Beirut: Dâr alKutub al-Ilmiyah, 1993), jld viii: 108.

${ }^{20}$ Abi Zakariya, Raudlah at-Thâlibîn wa Umdah al-Muftîn (Bairut: Dâr al-Fikr, 1995), jld II: 387.

${ }^{21}$ Abdul Wahhab al-Bagdhadi, al-Mu'awwanah al-Imâm Mâlik bin Anas (Beirut: Dâr al-Fikr, 1995), jld ii, 1163.

${ }^{22}$ Ahmad Jaudat dkk, Majallah al-A $\underline{h}$ kam al-Adliyah, cet. V (Ttp.t.p, 1968), 30.

${ }^{23}$ Ali bin Muhammad bin Ali al-Jurjaniy, al-Ta'rifat (Bairut: Dâr al-Kitab al-Arabiy, 1305), 69.

${ }^{24}$ Lexy J.Moleyong, Metodelogi Penelitian Kualitatif (Bandung: Remaja Rosdakarya, 2000), 3.
} 
sebagai kasus. ${ }^{25}$ Selanjutnya pendekatan yang digunakan adalah pendekatan fiqh atau normatif-sosilogi, ${ }^{26}$ artinya analisa data didekati dengan melihat latar belakang kondisi sosial yang mempengaruhi pemikiran keagamaan dan perilaku masyarakat Sasak Lombok, selanjunya dikaitkan dengan hukum Islam (al-Fiqh al-Islâmiy). Sementara teknik pengumpulan data dilakukan dengan melalui observasi non-partisipan, yaitu peneliti tidak terlibat langsung dalam yang diteliti, sehingga dengan terbuka peneliti menyatakan diri sebagai peneliti. ${ }^{27}$

Wawancara dilakukan guna mendapat informasi tentang praktek Sandak dengan membawa sejumlah pertanyaan tersusun, ${ }^{28}$ dan dokumentasi. Teknik sampling dalam penelitian ini adalah penggabungan antara purposive sampling dan snowball sampling dan tidak digunakan random sampling, ${ }^{29}$ dengan beberapa pertimbangan: 1) Tidak semua masyarakat mengetahui tentang Sandak. 2). Tidak semua masyarakat melakukan Sandak. Karena itu dalam hal ini responden dicari yang lebih mengetahui tentang Sandak, baik dari para pelaku (kreditur-debitur), para makelar dan masyarakat sendiri, karena merekalah yang dipandang berkompeten. ${ }^{30}$ Setelah data terkumpul dengan melalui berbagai cara di atas, selanjutnya dianalisa dan diberikan penafsiran sesuai dengan isi. ${ }^{31}$

Penelitian ini dilakukan di desa Bagu kecamatan Bagu, Kabupaten Lombok Tengah. Sementara alasan pemilihan lokasi penelitian adalah: 1) Mayoritas penduduknya sebagai petani. 2). Banyak masyarakat yang pergi ke Malaisiya sebagai TKI yang menggunakan hasil dari praktek Sandak 3). Di Bagu ada pondok pesantren "Qamarul Huda” yang dipimpin oleh TGH. Turmuzi, di mana posisi pondok ini adalah sebagai sentral keagamaan yang barang kali dengan posisi ini menjadi pencerah terhadap aktivitas masyarakat, baik dalam bidang ibadah atau muamalah.

${ }^{25}$ Haidar Nawawi, Metode Penelitian Bidang Sosial (Yogyakarta: Gajah Mada University Press, 1995), 72.

${ }^{26}$ Atha' Mudzhar, Studi Hukum Islam dengan Pendeketan Sosilogi (Yogyakarta: IAIN Sunan Kalijaga, 1999), 6.

${ }^{27}$ Irwan Suhartono, Metode Penelitian Sosial (Remaja Rosdakarya, 1998), 65.

${ }^{28}$ Masri Singaribuan Sofian Efendi, Metode Penelitian Survai (Jakarta: LP3S Indonesia, 1995), 192.

${ }^{29}$ Moleyong, Metodelogi..., 44.

${ }^{30}$ Noeng Muhajir, Metodelogi Penelitian Kualitatif (Yogyakarta: Rake Sarasin, 2000), 132.

${ }^{31}$ Sumardi Suryabrata, Metode Penelitian ( Jakarta: Raja Grafindo, 1998), 85. 


\section{Hasil Temuan Dan Pembahasan}

\section{A. Motivasi praktek Sandak}

Sandak merupakan salah satu cara bermuamalah dan sudah membudaya dalam masyarakat Sasak pada umumnya di Lombok. Terjadinya praktek Sandak disebabkan oleh keadaan tertentu yang dialami oleh seorang untuk menyelesaikan permaslahan tertentu, sehingga pada umunya Sandak dilakukan oleh sebagian masyarakat Sasak dengan beberapa motivasi -yang menjadi masalah yang tengah dihadapi baik dari pihak pemberi gadai atau penerima gadai- yang diantara adalah: a) bersifat konsumtif dan mendesak, seperti modal pernikahan anak, biaya sekolah, pembelian, motor, pergi berhaji, dan pergi ke Malaysia menjadi TKI. b). ${ }^{32}$ bersifat produktif, seperti mengembangkan usaha dan pembelian tanah..$^{33}$ Dengan dua motivasi tersebut, seorang yang melakukan Sandak harus jeli, sehingga ia tidak merasa rugi menggadaikan sawah/kebun dengan melakukan trik-trik yang menghasilkan uang sehingga pada waktu pengembalian ia dapat menebus kembali sawah, seperti yang dilakukan oleh H. Hasyim dan H. Syamsul Hakim. Mereka menggunakan sebagian pinjaman untuk membeli mobil dan sebagian didepositokan. Dengan cara yang demikian itu mereka dapat menebus sawah yang dijadikan jaminan. ${ }^{34}$

Sementara motivasi pemberi pinjaman tersimpul pada poin: a). Untuk menolong orang yang tengah mengalami kesusahan mendesak, seperti yang dialami H. Asy'ari diberikan pinjaman oleh H. Ramli guna melunasi ongkos haji. ${ }^{35}$ b). Untuk mengembangkan uang yang dipinjamkan, karena dua alasan: seandainya uang yang dipinjamkan itu tidak digunakan dalam bentuk usaha maka akan lebih menghasilkan daripada meminjamkan, walaupun ada penggarapan sawah, sehingga di sini adanya keinginan tolong menolong di samping dapat hasil. ${ }^{36}$ Karena faktor skill dimana pemberi pinjaman tidak bisa mengolah uang, maka jalan keluarnya adalah meminjamkan uangnya dan ia mendapatkan garapan sawah dari penerima pinjaman. ${ }^{37}$ Setelah terjadi akad Sandak, ada beberapa hak dan kewajiban bagi para pelaku.

Kewajiban tersebut terbagi menjadi dua: Pertama hak dan kewajiban terhadap pemberi gadai, yaitu: a) Ia harus menyerahkan sawah/kebun yang digadaikan kepada

\footnotetext{
${ }^{32}$ Wawancara dengan H. Misbah, Haji Asy Ariy, L. Suhaimi, L.Marzuki, dan Suparlan. Mereka adalah semua pemberi gadai guna menyelesaikan masalah yang dialaminya.

${ }^{33}$ Wawancara dengan Muktamad tgl. 24- Januari 2010.

${ }^{34}$ Ibid.

${ }^{35}$ Wawancara dengan H.Ramli dan Munawwir, 05- Pebruari 2010.

${ }^{36}$ Wawancara dengan Fauzi dan Idun tanggal 06 Pebruari 2010

${ }^{37}$ Wawancara dengan Khairuddin tanggal 06 Peberuari 2010
} 
penerima gadai. b). Ia berhak menggunakan uang yang diberikan oleh penerima gadai. c). Tidak boleh menghentikan akad di tengah jalan, kecuali dengan memindahkan ke orang lain. Kedua hak dan kewajiban bagi penerima gadai adalah sebagai berikut: 1). Ia berkewajiban memberi sejumlah uang kepada pemberi gadai. 2). Tidak boleh menagih sebelum habis waktu kontrak 3). Wajib mengeluarkan zakat dan pajak terhadap garapan. 4). Ia berhak menggarap sawah selama kontrak berlangsung. Berbagai motivasi dan hakkewajiban dalam praktek Sandak menjadi pemicu terjadinya Sandak yang dapat berimplikasi kepada dua hal, yaitu positif dan negatif. Implikasi positifnya bagi peminjam adalah dapat lolos dari masalah yang dihadapi. ${ }^{38}$ Sementara negatifya bagi peminjam adalah adanya beban penebusan sawah. Sementara ia orang yang tidak bisa mengolah uang yang dipinjamnya karena sekedar untuk kebutuhan yang bersifat konsumtif. Namun, sebaliknya, bagi orang yang butuh dana untuk mengembangkan usahanya, maka ia akan menjadi tertolong dan akan lebih beruntung. Sedangkan positifnya bagi pihak pemberi pinjaman adalah mendapatkan garapan sawah selama waktu yang disepakati. Dan negatifnya adalah pengembalian uang yang turun harganya sesuai dengan fluktuasi uang. ${ }^{39}$

Keengganan masyarakat untuk meminjam uang ke bank disebabkan oleh berbelitnya birokrasi, yaitu dengan persyaratan yang ketat di samping bunga yang tinggi. Apabila mereka tidak melunasi hutang, maka jaminan dapat dijual oleh pihak bank. Sementara dalam Sandak tidak dapat dijual, karena nilai jaminan tidak sebanding dengan peminjaman. ${ }^{40}$ Dengan demikian, maka alternatif jalan yang paling cepat, mudah, dan praktis adalah melalui praktek Sandak. Sebab banyak para makelar yang menjadi perantara yang dapat menghubungkan para pelaku.

\section{B. Sandak dalam perspektif hukum al-Qardl (pinjam-meminjam)}

Setelah diketahui bagaimana terjadinya praktek Sandak dalam masyarakat Sasak, dengan segala hak dan kewajiban antar pelaku yang ada di dalamnya, maka selanjutnya Sandak akan ditinjau dari perspektif dari hukum al-Qardl. Islam sebagai agama yang menjadi rahmat bagi alam tentunya dalam penerapan segala teori hukum-hukumnya akan berlandasakan kepada kemashlahatan, baik dalam rangka mendatangkan manfaat

\footnotetext{
${ }^{38}$ Wawancara dengan H.Mashudi tanggal 07 Pebruari 2010.

${ }^{39}$ Wawancara dengan Saharuddin tanggal 06 Pebruari 2010.

${ }^{40}$ Wawancara dengan Paitang tanggal 06 Pebrari 2010
} 
atau menghindari kemudaratan. ${ }^{41}$ Praktek al-Qardl juga mengandung kemaslahatan, yaitu memberikan kemudahan bagi manusia dalam menjalani kehidupan, sesuai dengan makna al-Qardh, yaitu memberikan hak milik harta kepada orang lain dengan syarat untuk dikembalikan tanpa ada lebih”. ${ }^{2}$

Penekanan dalam makna al-Qardl adalah bahwa seorang yang meminjam sesuatu berkewajiban mengembalikan sesuai dengan yang dipinjamnya tanpa ada tambahan. Pengembalian yang lebih dari pinjaman adalah termasuk riba. Sementara ulama lain memberikan makna al-Qardl dengan makna, yaitu: memberikan sesuatu kepada seorang dari yang dimilikinya agar ia -orang yang diberi- dapat mengembalikan seumpama (sepadan)nya dari tanggungannya secara langsung atau bertempo". ${ }^{43}$ Penegasannya bahwa pemberian pinjaman kepada seorang untuk diambil manfaatnya akan dikembalikan kepada pemberi sebagiamana pinjaman semula baik berupa benda ataupun harga, ${ }^{4}$ dengan tanpa adanya pengembalian lebih atas pinjaman karena dapat merusak akad. ${ }^{45}$

Untuk dapat dikatakan sah akad pinjam meminjam, para ulama memberikan persyaratan, yaitu: Pertama adanya dua pelaku (atau kelompok) yang melakukan akad alqardl. Kemudian para pelaku harus orang yang berakal, dapat melakukan tindakan hukum, melakukan transaksi tidak dalam terpaksa. Syarat pelaku yang sedemikian rupa diperlukan karena asas al-qardlitu adalah al-tabarru' (sumbagan semata). Oleh karena itu seorang wali tidak boleh meminjamkan milik anaknya tanpa ada kepentingan atau darurat. $^{46}$ Kedua, adanya shighat (pernyataan setuju) dari dua belah pihak, yang kemudian disebut dengan ijab dan qabul. Pernyataan setuju itu tidak terbatas hanya dengan ucapan, akan tetapi dapat pula dengan surat, isyarat, atau lainnya yang dapat dimengerti, sehingga ungkapan-ungkapan tersebut merupakan tanda setuju oleh para pelaku secara tegas. Ketiga, adanya benda yang dipinjamkan, yaitu sesuatu yang dapat diserahterimakan dan dapat dijualbelikan. ${ }^{47} \quad$ Transaksi al-qardl yang telah memenuhi persyaratan dan rukun dikatakan valid (sah) dan dipandang memiliki kekuatan hukum,

${ }^{41}$ Abdul Wahhab Khalaf, Ilm Ushûl Fiqh (Bairut: Dâr al-Qalam, 1978), 64.

${ }^{42}$ Musthafa al-Khin dkk. Al-Fiqh al-Minhaj 'ala Madzhab al-Imâm al-Syâfi'iy (Damasq: Dâr alQalam, 1992), jld vi, 103.

${ }^{43}$ Ibnu Hazm, al-Muhalla (Beirut: Dâr al-Fikr, tt), jld vi, 248.

${ }^{44}$ an-Nawawi al-Bantaniy, Nihâyah al-Zain fì Irsyâd al-Mubtadi' în (Bandung: Syirkah al-Ma'arif li alThaba; Wa al-Nasyar, tt), 240.

${ }^{45}$ Muhammad bin Ali al-Syaukaniy, al-Sail al-Jarar al-Mutadaffiq 'ala Hadâ'iq al-Azhar (Bairut: Dâr al-Kutubal-Ilmiyah, tt), jld iii, 143.

${ }^{46}$ Ibid., 104.

${ }^{47}$ Ibid. 
artinya transaksi itu dapat dipertanggungjawabkan.Walaupun demikian, ada beberapa hal yang dapat merusak akad al-qardl, yaitu persyaratan yang dibuat oleh para pelaku, diantaranya adalah:

- Syarat yang dikategorikan sebagai syarat yang merusak “"الثروط المفسدة”, yaitu segala bentuk persyatan yang tidak sesuai dengan eksistensi akad al-qardl, di mana dalam syarat tersebut ada manfaat bagi yang memberikan pinjaman (المقرض), seperti keharusan untuk mengembalikan dengan nilai lebih dalam pinjaman, atau disyaratkan pengembalian yang lebih bagus. Syarat semacam seperti ini rusak dengan sendirinya dan dapat merusak eksistensi akad, karena tidak sesuai dengan akad. Karena pada hakekatnya fungsi akad al-qardl adalah "al-irfaq wa al-'aun” (akad membantu semata). Persyaratan di atas dapat membawa kepada riba, sesuai dengan ungkapan berikut: "Setiap peminjaman yang menarik keuntungan adalah termasuk riba" ${ }^{18}$ Menurut hadis ini, terlepas dari penilaian terhadapnya, maka setiap persyaratan yang dibuat oleh pemberi hutang yang menguntungkannya adalah tidak dibenarkan, karena dapat merugikan peminjam. Kecuali dalam hal tertetu dibolehkan, seperti penggantian lebih karena merupakan rasa terima kasih dari peminjam (secara ikhlas), sebagai hadiah setelah hutang telah berakhir. Sementara bila pelunasan hutang belum selesai adalah lebih baik untuk dihindari. ${ }^{49}$

- Syarat dikategorikan sebagai syarat yang sia-sia, tetapi eksistensinya tidak merusak akad “الشروط اللاغية غير المفسدة للعقد”. Seperti persyaratan yang dibuat oleh pemberi pinjaman agar peminjam mengembalikan pinjaman dengan sesuatu lebih jelek. Hukum untuk memenuhi persyaratan ini adalah tidak wajib, baik bagi debitur maupun kreditur, karena syarat tersebut tidak berkenaan dengan eksistensi akad, malah menguntungkan penerima pinjaman meski persyaratan ini tidak merusak eksistensi akad..$^{50}$

- Syarat yang harus dipenuhi oleh penerima pinjaman untuk dapat melunasi hutang atau "ما يلزم الوفاء به من الثروط". Syarat semacam ini adalah sebagai penguat atas

${ }^{48}$ al-Shan'niy, Subl al-Salâm Syarh Bulûgh al-Marâm (Makkah: Jami’h al-Imam Muhammad bin Su'ud al-Islamiyah, 1408H), jld ii, 49. Selanjutnya untuk lebih jelasnya mengenai ungkapan di atas lihat footnote (17). Walaupun sebagian ulama hadis menganggap bahwa hadis di atas kurang kuat, karena seorang yang bernama Siear bin Mash'ab al-Hamaznait al-'Ama yang tidak tesebutkan, namun banyak hadis yang dapat mendukungnya sehingga dapat menjadi kuat, seperti hadis: "كل قرض يجر منفعة فهو وجوه الربا.) (setiap peminjaman yang menarik manfaat maka ia adalah satu bentuk dari riba). Imam Bukhariy berpendapat tentang hadis di atas mauquf dari Abdullah bin Salam, sebagai hadis yang melarang tentang peminjan bersyarat yang menguntungkan. Lihat Sabiq, Fiqh al-Sunnah, 184.

${ }^{49}$ Ibid.

${ }^{50}$ Ibid., 111. 
hutang, seperti syarat keharusan adanya jaminan, transaksi di depan hakim, keharusan adanya saksi, penulisan dan lainnya, yang dapat menerangkan adanya akad al-qardl. Dalam hal ini pemberi pinjaman harus mengemukakan persyaratan tersebut. Bila penerima pinjaman tidak mau memenuhi persyaratan tersebut pemberi pinjaman berhak menggagalkan akad al-qardl. ${ }^{5 l}$

Selanjutnya bila praktek Sandak dikaitkan dengan al-qardl berserta hal yang terkait dengannya, seperti rukun, syarat, ataupun persyaratan yang dibuat oleh pelaku, maka ditemukan beberapa kemiripan. Di antara kemiripan itu adalah dalam hal pemberi pinjaman harus menggarap sawah/kebun yang dijadikan jaminan, sehingga seolah-seolah di sini menjadi keharusan yang tidak dapat dihindari. Tidak pernah terjadi Sandak tanpa ada penggarapan sawah oleh pemberi pinjaman, karena orang tidak akan memberikan pinjaman dalam jumlah yang banyak berkisar 5 juta sampai 20 juta dalam kurun waktu 3-5 tahun. Sebab uang yang akan dipinjamkan itu bisa untuk mengembangkan usahanya, dan terkadang peminjam menghilang tanpa arah dan tanpa ada jaminan.

Oleh karena itu, pada dasarnya Sandak mirip dengan akad al-qardl tetapi terdapat syarat yang merusak di dalamnya. Akan tetapi, apakah persyaratan semacam ini yang terjadi dalam Sandak itu merupakan adat atau tidak? Bila ia sudah menjadi adat, maka menurut pandangan sebagian ulama adalah tetap tidak boleh. Dalam hal ini Sayyid Sabiq menyatakan:

$$
\text { الحرمة مقيدة هنا بما إذا كان نفع اللقرض مشروطا أو متعارفا عليه }
$$

"Keharaman -mengambil manfaat untuk pemberi pinjaman- adalah terikat pada apabila manfaat untuk pemberi pinjaman adalah merupakan syarat ataupun merupakan adat”. ${ }^{52}$

Jadi tegasnya, menggarap sawah/kebun yang hampir pasti terjadi, dan merupakan bagian, dalam transaksi Sandak dapat menyeret kepada ketidakabsahannya. Akan tetapi bila dalam adat berlaku pembayaran lebih terhadap hutang, maka cara yang demikian itu dianggap boleh menurut pandangan sebagian ulama, karena alasan apakah adat itu berfungsi sebagai syarat atau tidak. Imam as-Suyuthiy mengatakan:

لو جرت عادة المقترض برد أزيد مما اقترض فهل ينزل منزلة الثرط فيحرم اقتر اضها؟ وجهان،

${ }^{51}$ Ibid., 112.

${ }^{52}$ Ibid., 184.

${ }^{52}$ Ibid. 
"Jika berlaku adat penerima pinjaman dengan mengembalikan lebih dari yang dipinjamnya, maka apakah hal ini sama dengan syarat, sehingga haram meminjam? -Jawabannya ada dua, dan -yang dianggap palingbenar adalah tidak (menjadi syarat)".

Dengan mengambil dua pandangan di atas maka dapat ditegaskan bahwa status hukum Sandak masih diperselisihkan, karena pembayaran lebih dari pinjaman -dalam hal ini penggarapan sawah oleh pemberi pinjaman- yang berlaku dalam adat sebagai syarat. Dalam hal ini, ulama Syafi'iyah mengganggap tidak menjadi syarat. Ulama lain memiliki pandangan yang berbeda, yaitu karena justru menjadi adat telah menjadikan sebagai hal yang terlarang karena dianggap sebagai syarat.

\section{Sandak dalam Perspektif Hukum al-Rahn (Gadai)}

Salah satu bentuk transaksi dalam bermuamalah adalah al-rahn yang sama halnya dengan al-qardl sebagai jalan untuk memenuhi kebutuhan dalam kehidupan manusia. Pengertian al-rahn yang diberikan oleh ulama adalah: "Menjadikan uang (harta) sebagai penguat atas hutang yang akan dijadikan sebagai pelunas atas hutang pada saat tidak sanggup membayar (hutang itu). ${ }^{5_{44}}$ Jadi, al-rahn adalah sebagai penguat atas hutang yang dipinjam seorang. Karena sering terjadi dalam bermuamalah, seseorang tidak mengakui hutangnya, atau orang yang berhutang menghilang, sehingga pemberi pinjaman dirugikan. Oleh karena itu dibutuhkan suatu penguat atas hutang dari suatu yang dapat perjualbelikan..$^{55}$ Untuk sahnya sebuah akad al-rahn ditetapkan beberapa rukun yang sama dengan jual beli, yaitu di antaranya adalah:

1. Al-Râhn (pemberi gadai/jaminan) atas hutang yang dipinjamnya dari orang lain orang yang menerima gadai- (al-murtahin). Orang memberikan gadai disyaratkan harus mampu berbuat hukum. ${ }^{56}$ Orang gila tidak dianggap sah transaksinya sebab ia tidak dapat melakukan tindakan hukum.

2. Al-Murtahin, yaitu orang yang menerima gadai. Sebenarnya posisi antara al-râhn dan al-murtahin adalah satu kesatuan yang tidak dapat dipisahkan, karena keduanya adalah orang-orang yang melakukan transaksi..$^{57}$ Oleh karena itu disyaratkan pula bahwa mereka adalah orang-orang yang dapat melakukan tindakan hukum.

\footnotetext{
${ }^{53}$ Jalâl al-Dîn al-Suyuthiy, al-Ashbâh al-Nazhâ'ir (Bairut: Dâr al-Fikr, tt), 106.

${ }^{54}$ Abi Zakariya al-Anshariy, Fath al-Wahhâb bi Syarh Minhaj al-Thâlibîn (Semarang: Maktabah Wa Mathba'ah Toha Putra, tt), jld ii, 192.

${ }^{55}$ Muhammad Syatha' al-Dimyathiy, 'I'ânah al-Thâlibîn (Semarang: Maktabah Wa Mathba'ah Toha Putra, tt), jld iii, 54.

${ }^{56}$ Khalaf, Ilmu ..., 138.

${ }^{57}$ Syaikh Ahmad al-Syawi, Bulghah al-Sâlik li Aqrab al-Masâlik (Bairut: Dâr al-Fikr, tt) jld ii, 101.
} 
3. Al-Marhûn, yaitu barang yang digadaikan. Dalam hal ini, menurut mazhab Syafi’i bahwa barang yang dijadikan sebagai jaminan memiliki syarat tertentu, yang antara lain: pertama, harus berupa barang/benda, sehingga seorang tidak boleh menggadaikan hutang. Kedua, tanggung jawab pemberi gadai atas benda yang digadaikan tidak dapat dicegah oleh penerima gadai. Ketiga, barang yang digadaikan adalah barang layak jual ketika habis masa pinjaman hutang. Dalam hal ini berbeda dengan pandangan Imam Malik yang menyatakan kebolehan yang demikian itu. ${ }^{58}$ Tehadap barang yang masih umum dalam perserikatan menurut Imam Maliki dan Syafi'i tidak boleh dijadikan sebagai jaminan, sementara Imam Hanafi membolehkan. Perbedaan pandangan ini disebabkan oleh adanya atau kemungkinan barang umum dikuasai. ${ }^{59}$

4. al-Marhûn bih, yaitu adanya pokok pinjaman dari peminjam atau merupakan harga barang yang belum terbayar oleh pembeli dengan sebab hutang kreditur kepada debitur yang merupakan sebab terjadi transaksi al-rahn. ${ }^{60}$

5. al-Shighah, yaitu pernyataan setuju. Dalam hal ini, ulama Hanafiyah memberikan persyaratan, yaitu tidak digantungkan pada persyaratan tertentu dan tidak pula untuk masa tertentu. Bila shighah itu melanggar syarat tersebut, maka akad al-rahn menjadi batal (rusak) sebagaimana dalam hal jual beli. ${ }^{61}$ Sementara ulama Syafi'iah memberikan persyaratan dan membaginya kepada: 1). Syarat yang dianggap benar, yaitu persyaratan yang dituntut untuk memenuhi pembayaran hutang. 2). Syarat yang sia-sia, yaitu persyaratan yang tidak memiliki kemaslahatan, seperti tidak memberikan makan hewan yang dijadikan jaminan. 3). Syarat yang rusak, yaitu persyaratan merugikan sepihak. ${ }^{62}$ Ulama Malikiyah dan Hanabilah memberikan dua persyaratan: a). Persyaratan yang benar dan b) persyaratan yang rusak. Persyaratan yang benar adalah persyaratan yang sesuai dengan kemaslahatan akad al-rahn. Sementara syarat yang rusak adalah persyaratan tidak memiliki kemaslahatan bagi akad, seperti adanya persyaratan penggunaan barang gadai oleh penerima gadai. ${ }^{63}$

${ }^{58}$ Ibnu Rusyd, Bidâyah al-Mujtahid wa Nihayah al-Muqtashid (Semarang: Maktabah Wa Mathba'ah Toha Putra, tt), jld i, 205.

${ }^{59} \mathrm{Ibid}$.

${ }^{60}$ Ahmad al-Hajawi, al-Raudl al-Murabba' bi Syarh Zad al-Mustqna' Mukhtashar al-Muqna' (Bairut: Dâr al-Kutub al-Ilmiyah, 1988), jld i, 215.

${ }^{61}$ Wahbah al-Zuhaili, al-Fiqh al-Islâmiy wa Adillatuh (Bairut: Dâr al-Fikr, 1989), jld v, 190.

${ }^{62}$ Ibid., 191.

${ }^{63}$ Ibid., 193. 
Melihat persayaratan yang ada dalam al-rahn, maka dapat diketahui bahwa penggarapan sawah/kebun yang terjadi dalam praktek Sandak dapat dikatakan sebagai syarat terjadinya al-rahn walaupun tidak tersebut dalam shighat akad. Karena kadang kala shighat akad tidak terucapakan, akan tetapi dapat diwakili oleh sesuatu yang dapat menunjukkan akan terjadinya transaksi gadai. Jelasnya, bahwa syarat yang rusak dapat merusak akad al-rahn, karena akan merugikan satu pihak dan dengan demikian akad batal demi hukum. ${ }^{64}$ Dari penjelasan di atas, dapat diketahui di mana sisi persamaan Sandak dengan al-rahn. Apabila dilihat dengan seksama, maka praktek Sandak adalah sama dengan gadai, di mana persamaan itu terlihat pada cara pelaksanaan yang dilakukan masyarakat Sasak yang dilakukan dengan sistem gadai.

Penggarapan sawah/kebun dalam praktek Sandak yang dilakukan oleh penerima gadai, bila dikaitkan dengan hukum al-rahn, maka menurut pandangan beberapa madzhab adalah diperselisihkan. Pertama, menurut pandangan madzhab Maliki adalah tidak boleh, karena yang berhak atas barang gadai adalah pemilik barang, yaitu pemberi gadai, sebagaimana diungkapkan: "Hasil dari barang gadai dan apa yang dihasilkanya adalah milik pemberi gadai" ${ }^{65}$ Dari itu, ditegaskan bahwa pengambilan manfaat oleh penerima gadai adalah tidak boleh. Senada pandangan ini adalah pandangan Syafi'iyah sebagai pandangan kedua, di mana ketidakbolehan itu terungkapkan dengan ungkapan:

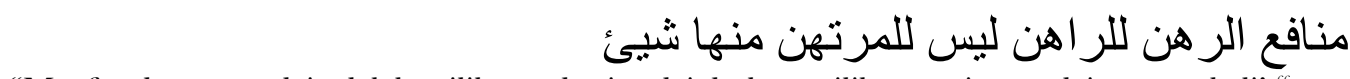

"Manfaat barang gadai adalah milik pemberi gadai, bukan milik penerima gadai sama sekali'."

Ditegaskan bahwa penerima gadai tidak memiliki hak sama sekali dalam barang gadai, karena gadai itu berfungsi sebagai penguat atas hutang saja, sehingga ia bukanlah pemilik hak penuh terhadap barang gadai, karena ia akan bertanggungjawab atas barang gadai bila terjadi kerusakan, dan dia pula yang berhak atas hasil dari barang gadai tersebut. ${ }^{67}$

Padangan yang sama juga dilontarkan oleh madzhab Hanbali sebagai pandangan yang ketiga. Dijelaskan bahwa penerima gadai tidak berhak mengambil manfaat atas gadai, sebab barang gadai adalah milik pemberi gadai. Hal ini djelaskan dengan ungkapan:

${ }^{64}$ Ibid., 195.

${ }^{65}$ Abdurrahman al-Jaziriy, al-Fiqh alâ Madzâhib al- 'Arba'ah (Bairut: Dâr al-Qalam, tt), jld ii,, 332.

${ }^{66}$ Muhammad bin Idrîs al-Syâfi'iy, al-Umm (Bairut: Dâr al-Ma'rifah, 1393 H), jld iii, 155.

${ }^{67} \mathrm{Di}$ sini Imam Syâfi'i mengemukan sebuah hadis yang artinya: "Gadai itu tidak tertutup bagi pemilik yang menggadaikannya, dia berhak atas hasilnya dan bertanggung jawab atas kerusakannya”.. Lihat dalam al-Syâfi'i, Musnad al-Syâfi'iy (Beirut: Dâr al-Kutub al-Ilmiyah), 148, dan lihat pula al-Daruquthniy, Sunan al-Daruquthniy (Bairut: Dâr al-Ma'rifah, 1966), jld iii, 33. 
"Tidak boleh bagi penerima gadai mengambil manfaat dari barang gadai tanpa ada izin pemberi gadai... (Selanjutnya dikatakan) karena manfaat itu milik pemberi gadai, maka ia tidak boleh mengambil manfaat itu tanpa ada izin darinya, sebagaimana dalam hal lainnya, kecuali barang gadai itu berupa binatang yang dapat ditunggangi atau diperah...Selanjutnya apabila pemberi gadai mengizinkan bagi penerima gadai untuk mengambil manfaat tanpa ada pengembalian, sementara gadai dalam bentuk peminjaman, maka hal itu tidak boleh, karena dapat terjadi peminjaman yang mengambil untung, tetapi jika tidak demikian adalah boleh, karena tidak ada (keuntungan) yang demikian itu" ."

Tegasnya pandangan tiga madzhab di atas melarang bagi penerima gadai untuk mengambil manfaat dari barang gadai, sebab pemilik barang yang hakiki adalah pemberi gadai. Sementara padangan madzhab Hanafi sebagai pandangan keempat, menyatakan bahwa penerima gadai boleh mengambil manfaat atas barang gadai. Sebab dalam hal ini barang gadai itu berada dalam tangan penerima gadai, dan apabila diberikan izin oleh pemberi gadai maka tidak ada halangan untuk mengambil manfaat darinya. Hal ini sesuai dengan ungkapan berikut:

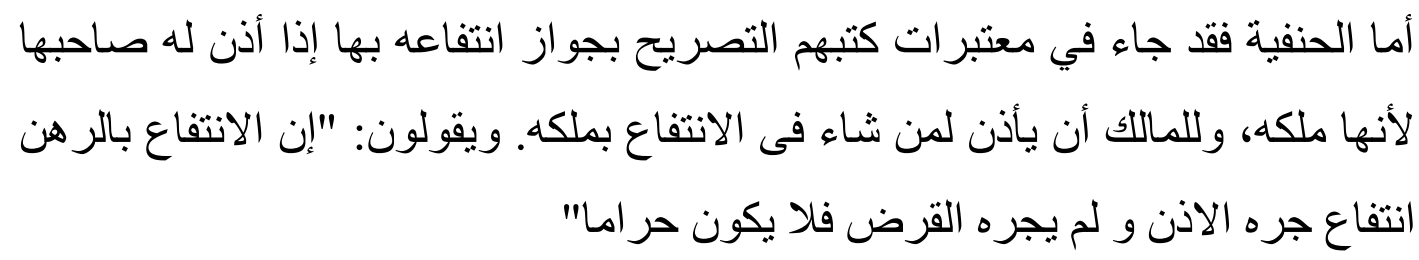

“Adapun ulama Hanafiyah dalam kitab-kitab mu’tabar-nya ada penjelasan tentang kebolehan mengambil manfaat dari barang gadai apabila ada izin pemiliknya, karena ia pemiliknya. Pemilik dapat saja memberikan izin kepada siapa saja yang diinginkannnya dalam memanfaatkan barang gadai. Mereka berkata: "Sesungguhnya mengambil manfaat dari barang gadai adalah diberlakukan atas izin bukan hutang, sehingga tidaklah menjadi haram”. ${ }^{9}$

Selain itu, Kebolehan mengambil manfaat oleh penerima gadai telah diundang dalam KUHP Islam (Majjalah al-Ahkam al-'Adliyah) pada masa Turki Usmaniy yang bersumber pada madzhab Hanafi. ${ }^{70}$ Dalam Pasal 2 tentang Penggunaan Barang

\footnotetext{
${ }^{68}$ Ibnu Qudamah al-Muqaddasi, al-Kâfi fi Fiqh al-Imâm al-Mujabbal Aḥmad bin Hanbal (Beirut: alMaktabah al-Islamiy, 1988), jld ii, 147-8.

${ }^{69}$ Mahmûd Syaltut, al-Fatawâ (Beirut: Dâr al-Qalam, tt), 345.

${ }^{70}$ Mengenai KUHP Islam dalam hal penyusunan Majallah didominasi oleh pendapat yang datang dari kalangan madzhab Hanafi, karena keberadaan madzhab Hanafi menjadi madzhab resmi Kerajaan Turki Usmani. Di samping itu juga bahwa pandangan madzhab ini dianggap mampu sebagai tolok ukur hukum kehidupan sosial masyarakat, yang akan berpacu dengan kemajuan Barat. Selain itu juga dirasakan sulit untuk menyeleksi seluruh madzhab yang ada sebagai acuan dalam penyusunan Majallah. Karena keadaan yang mendesak untuk menyeleksi semua kitab fiqh, maka diprioritaskan pada madzhab Hanafi saja, sesuai dengan ungkapan penyusun Majallah:

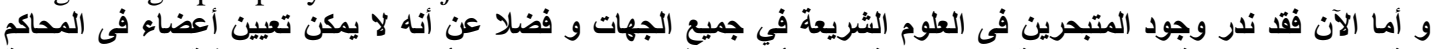

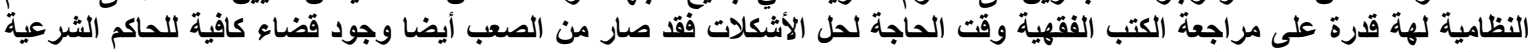

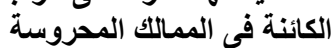

Hal ini juga dijelaskan dalam Majallah sendiri, bahwa berdasarkan keinginan yang tinggi, maka tersusunlah kitab yang bebas dari perselisihan pendapat dan terpilihnya pendapat dari ulama' Hanafiyah, sesuai dengan ungkapan penyusun Majallah sebagai berikut:
} 
Gadai ayat 750 dinyatakan sebagai berikut: "Pada dasarnya penerima gadai tidak berhak atas barang gadaian tanpa ada izin dari pemberi gadai. Adapun bila diberikan izin dan dibolehkan untuk mengambil manfaat, maka bagi penerima gadai boleh menggunakannya dan boleh pula mengambil hasil serta susu -binatang- dan hutangnya tidak berkurang sedikitpun karenanya". ${ }^{71}$

Jelaslah bagi mazhab Hanafi bahwa pengambilan manfaat atas barang gadaian, seperti yang jelas terjadi dalam Sandak, yang dilakukan oleh penerima gadai adalah boleh, apabila disertai dengan adanya izin dari pemilik barang. Tentunya perizinan itu harus keluar dari perasaan yang ikhlas dan rela, tidak dibarangi dengan rasa terpaksa ataupun hal yang lain yang dapat membuat akad menjadi cacat.

\section{Sandak dalam Perspektif Hukum al-Riba (Riba)}

Dapatkah dikatakan bahwa praktek Sandak mengandung unsur riba? Untuk hal ini perlu dicermati dengan seksama, karena mungkin saja ada dan tidak ada unsur riba di dalamnya. Pengertian riba adalah "Riba adalah tambahan yang diambil oleh pemberi hutang sebagai bandingan atas pinjaman atau tambahan yang diambil oleh pembeli sebagai bandingan atas penangguhan pembayaran barang" ${ }^{72}$ Dari pengertian ini ditegaskan bahwa riba itu terjadi pada dua tempat; jual beli yang bertambah harga dikarenakan pembayaran bertempo dan pengembalian lebih atas jumlah hutang. Para ulama sepakat akan keharaman riba, akan tetapi mereka tidak sepakat mengenai ukuran riba dan apa yang dimaksud dengan riba. Oleh karenanya, sesungguhnya problem riba adalah masalah ijtihad, apalagi Nabi sendiri tidak pernah menjelaskan secara tuntas, sehingga banyak menimbulkan pernafsiran dan sungguhpun aksioma riba itu telah dicoba untuk dibedakan dengan interest (bunga). ${ }^{73}$ Selanjutnya, walaupun riba masih bersifat ijtihadiyah, akan tetapi para ulama membagi riba itu menjadi tiga bagian:

\footnotetext{
و بموجب الإرادة العلية اجتمعنا في دائرة ديوان الأحكام و بادرنا إلى ترتيب مجلة مؤلفة من المسائل و الأمور الكثيرة الوقوع

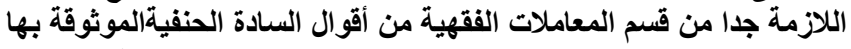

${ }^{71}$ Jaudat dkk, Majallah., 141.

${ }^{72}$ Muhammad Faruq al-Nabhan, al-Ittijah al-Jamâ 'iy fî̀ al-Tasyrî' al-Iqthishâdiy al-Islâmiy (Beirut: Mu'assah al-Risalah, 1984), 396.

${ }^{73}$ S.E. Rayner, The Theory of Contracts in Islamic Law (London: Graham dan Trotman, 1991), 266. Karena adanya perbedaan antara riba dengan intrests, maka ada sebagian ulama membolehkan mengambil bunga bank, dan hal ini dianggap sebagai hasil ijtihadnya. Lihat Fauzi Atwi, al-Iqtishâd wa al-Mâl fì alTasyrî' al-Islâmiy wa al-Nuzhûm al-Wadl'iyah (Beirut: Dâr al-Fikr al-Arabiy, 1988), 83. Selain itu ulama Indonesia juga memberikan penegasan terhadap kebolehan mengambil bunga bank, seperti yang dikemukakan oleh Ahmad Hasan, seperti yang ditulis Ahmad Minhaji dengan judul Ahmad Hasan and Islamic Reform 1887-1958 (Yogyakarta: Kurnia Kalam Semesta Press, 2000), 213.
} 
- Riba al-Jahiliyah, yaitu riba yang dipraktikkan pada masa jahiliyah, seperti seorang yang menjual barang dengan cara mengutangkan dalam tempo tertentu. Apabila pembeli tidak dapat memabayar pada saat yang sudah ditentukan, maka ia menambah harga penjualan akibat penundaan pembayaran tersebut. ${ }^{74}$ Contoh lain adalah seseorang memberikan pinjaman kepada orang lain dan apabila jatuh tempo dalam pembayaran, maka ia menambah harga pinjaman atas penundaan tersebut. ${ }^{75}$

- Riba al-Nasi'ah, yaitu "penambahan yang didapatkan oleh pemberi hutang sebagai bandingan atas bertemponya pembayaran". ${ }^{76}$ Mengenai bentuk riba ini oleh sebagian ulama dianggap sebagai satu-satunya yang dilarang dengan alasan hadits yang berbunyi: “لا ربا إلا فى النسيئة" (tidak ada riba kecuali riba al-nasi’ah) Anggapan ini dibantah oleh jumhur ulama yang mengatakan bahwa yang dimaksud oleh hadis di atas adalah bahwa tidak ada sekejam-kejam riba kecuali riba al-nasiah.

- Riba al-Fadl adalah bentuk riba yang terjadi dalam takar-menakar bahan pokok, yaitu penukaran jenis barang sama, tetapi dengan kadar yang berbeda baik sedikit maupun banyak. $^{78}$ Pelarangan bentuk riba ini berdasarkan hadis yang menjelaskan bahwa Rasulullah Saw melarang jual beli barter semacam garam, mas, perak, kurma, dll, kecuali dengan sama ukurannya dan apabila terjadi lebih maka terjadilah riba. ${ }^{79}$ Sementara illah pelarangan terebut adalah jenis harga dan jenis makanan. ${ }^{80}$

- Riba al-Qardl, yaitu salah satu bentuk riba yang disebabkan hutang yang menghasilkan keuntungan yang disyaratkan oleh pemberi hutang (al-muqtarid) kepada penerima hutang (al-muqtarad $)^{81}$ Pengertian ini senada dengan definisi yang diungkapkan oleh al-Bajuriy dengan ungkapan:

$$
\text { ربا القرض هو كل قرض جر نفعا للمقترض غير نحو رهن }
$$

"Riba al-Qardh adalah setiap peminjaman yang menarik keuntungan bagi pemberi hutang selain keuntungan semacam jaminan". ${ }^{2}$

${ }^{74}$ Ibnu Jarîr, Tafsîr Ibnu Jarîr (Beirut: Dâr al-Qalam, 1987), jld ii, 120.

${ }^{75}$ Abu Bakar al-Jashash, al-Ahkâm al-Qur'ân (Beirut: Dâr al-Fikr, 1996), jld ii, 221.

${ }^{76} \mathrm{Abu}$ 'Ala al-Maududiy, al-Ribâ (Beirut: Dâr al-Fikr, tt), 80.

${ }^{77}$ Muhammad Ismâ'îl Abu Abdillah al-Bukhâriy, al-Jâmi' al-Shahîh $\underline{h}$ al-Mukhtashar (Beirut: Dâr Ibnu Kasim 1989), jld ii, 762 hadis ke 2069 pada Bab “Bay al-Dinar bi al-Dinar al-Nasi'ah".

${ }^{78}$ al-Khin dkk., al-Fiqh, 65.

${ }^{79}$ Hadis ini banyak dimuat dalam berbagai koleksi kitab hadis, diantaranya Abu Daud, Sunan Ibnu Majah, Baihaqiy, Musnad al-Syafi'i dan lainnya.

${ }^{80}$ al-Nawawi, al-Majmu' 380, dan lihat Rayner, The Theory, 266.

${ }^{81}$ Muhammad Syafi'i Antonio, Bank Syari'ah dari Teori ke Praktek (Jakarta: Gema Insani Press, 2001), 38 .

${ }^{82}$ al-Bajuriy, Syarh al-Bajuriy (Beirut: Dâr al-Fikr, tt), jld i, 343. 
Persyaratan yang dibuat oleh pemberi pinjaman adalah hal yang memberatkan bagi penerima pinjaman. Disamping itu, persyaratan tersebut juga dapat menjadikan rusaknya akad. ${ }^{83}$ Dengan demikian terjadinya riba al-qardl ini adalah disebabkan oleh adanya persyaratan yang menguntungkan bagi pemberi hutang pada saat transaksi, tapi apabila persyaratan ini dibuat demi kemaslahatan akad, seperti adanya jaminan, maka persyaratan itu adalah boleh.

Selanjutnya dapat dianalisa apakah Sandak masuk dalam kategori salah satu riba tersebut di atas. Kecenderungan dalam memberikan legitimasi terhadap praktek Sandak yang sedemikian rupa muncul karena pemanfaatan barang berupa sawah atau kebun oleh pemberi hutang mesti terjadi, sehingga ia menjadi suatu keharusan, bahkan menjadi syarat. Karena sangat sulit memberikan sejumlah pinjaman dalam jumlah yang cukup besar pada masa yang lama, yaitu berkisar 2-5 (tahun), bukan hitungan hari atau bulan, tanpa ada “jasa lain” yang diterima pemberi hutang. Penggarapan sawah atau kebun itulah yang mejadi masalah dalam Sandak; apakah hal ini dianggap sebagai kelebihan dari pembayaran hutang atau tidak. Kalau ya, maka jelas merupakan kategori riba al-qardl, sebab akan menguntungkan bagi yang meminjami, disamping dia juga menerima pelunasan hutang dengan utuh. Oleh karena itu apakah sama pelaku Sandak dengan rentenir? Pada satu sisi jawabanya tidak, karena para rentenir tidak peduli dengan para peminjam apakah miskin atau kaya. Mereka hanya berprinsip mendapatkan uang dari peminjam dengan tanpa ada usaha, sehingga apa yang diberikan merupakan modal untuk mendapatkan keuntungan tanpa ikut serta dalam usaha. Pada sisi lainnya adalah ya, jika pemberian pinjaman itu dijadikan modal untuk mendapat keuntungan berupa penggarapan sawah/kebun. Hal ini disebut dengan riba al-qardl dan dapat pula dikategorikan sebagai riba al-fadl, dengan asusmi bahwa seorang yang meminjamkan suatu (hutang) dalam satu jenis kepada orang lain sehingga seolah-seolah ia menjual kepada orang lain dengan adanya lebih yang kembali kepada orang tersebut (pemberi pinjaman). ${ }^{84}$ Karena itu riba al-qardl termasuk juga dalam kategori riba al-fadl sesuai dengan ungkapan Sulaiman al-Bajuriy: "-Salah satunya adalah- riba al-Fadl, dan termasuk dalam riba al-Fadl itu adalah hutang yaitu dengan disyaratkan mengambil manfaat terhadap semacam barang gadai”. Dengan demikian, dapat ditegaskan bahwa

${ }^{83}$ al-Bantaniy, Nihâyah, 242.

${ }^{84}$ Abdul Hâmid al-Syarwaniy, al-Syarwaniy alâ Tuhfah al-Minhaj bi Syarh al-Minhaj (Beirut: Dâr alFikr, tt), jld iv, 247. 
praktek Sandak yang menjadikan penggarapan sawah sebagai suatu hak penerima gadai merupakan suatu kemiripan dengan riba al-qardl atau riba al-fadl. Walaupun demikian ada suatu pernyataan yang menarik untuk diperhatikan berkaitan dengan Sandak, yaitu:

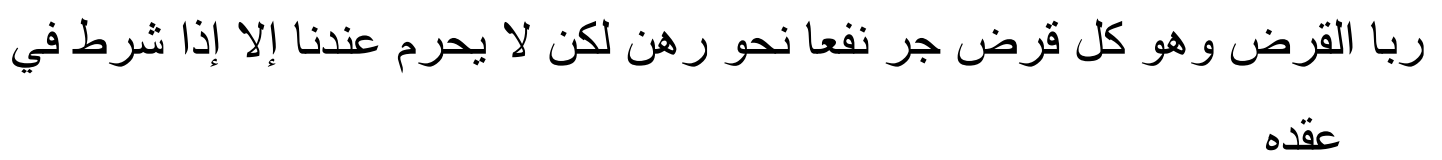

"Riba al-qardh adalah setiap peminjaman yang menarik manfaat semacam gadai, akan tetapi -hal itutidak menjadi haram kecuali persyaratan itu disebutkan dalam pangkal akad, menurut pandangan kami”.

Tegasnya, dari pandangan di atas, dapat dikatakan bahwa bagaimanapun praktek Sandak, ia bisa dikategorikan sebagai praktek riba al-qardl. Akan tetapi Sandak menjadi boleh dilakukan selama persyaratan penggarapan sawah oleh pemberi pinjaman tidak disebut dalam akad al-qardl.

\section{Analisa Argumentasi Pelaksanaan Sandak dalam Masyarakat Sasak}

Dari beberapa tinjauan teori hukum di atas, yaitu al-qardl, al-rahn, dan al-riba, dapat ditegaskan bahwa dalam Sandak ada unsur yang mengarah kepada hal-hal yang tidak dibolehkan, sebagaimana telah dijelaskan terutama dalam persyaratan Sandak. Akan tetapi bagaimana sebagian masyarakat Sasak melakukan praktek Sandak? Menurut hasil temuan peneliti bahwa mereka melakukan dengan dua cara:

1. Sistem gadai yang disertai dengan permohonan oleh penerima gadai kepada pemberi gadai. Kemudian istilah ini dinamakan dengan istilah "pinjam uang pinjam sawah”. Dalam hal ini pemilik uang menyerahkan sejumlah uangnya untuk dipergunakan dan pemilik sawah/kebun menyerahkan sawah/kebun untuk digarap selama waktu yang ditentukan. Di sana ada izin dari pemberi gadai untuk digarap sawahnya, dan begitu juga pemilik uang memberikan izin untuk digunakan uangnya.

2. Cara lain yang digunakan adalah cara yang disebut dengan "jual beli sementara" artinya pemilik sawah/kebun memberikan harga tertentu, selanjutnya pembeli menyerahkah sejumlah uang yang ditentukan, di mana benda dan harga akan kembali ke masing-masing penjual dan pembeli pada waktu yang sudah ditentukan

${ }^{85}$ Muhammad Syatha' al-Dimyathiy, Hasyiah 'I'ânah al-Thâlibîn 'alâ lî al- 'Alfâzh Fath al-Mu'în (Beirut: Dâr al-Fikr, tt), jld iv, 20. 
atau kapan saja pembeli dapat mengembalikan harga kepada penjual, maka barang akan kembali kepada penjual.

Dari cara di atas dapat ditelusuri apakah tata cara yang dilakukan dalam Sandak dapat dikatakan sebagai hilah (fiksi hukum). Hal ini akan bergantung sekali pada bagaimana sikap yang sesungguhnya dari para pelaku, yaitu apakah menghindari dari riba al-qardl -sesuai dengan pembahasan sebelumnya- yang dikandung oleh Sandak. Tapi kenyataan yang ada adalah bahwa sudah menjadi kebiasaan masyarakat melakukan Sandak dengan dua cara di atas. Kalau dikatakan hilah, maka jelas hal itu tidak mengapa, sebab dalam beberapa hal Imam Syafi’i menegaskan bahwa apabila suatu akad disebutkan di dalamnya persyaratan yang merusak pangkal akad, maka akad itu menjadi batal (tidak sah), dengan mengesampingkan tujuan dan niat pelaku. Hal ini sesuai dengan ungkapan beliau:

"Dasar yang aku pegangi bahwa setiap akad adalah pada dasarnya menjadi valid dalam kenyataanya, aku tidak membatalkannya hanya karena sangka belaka dan bukan pula karena adat. Tapi aku membolehkan semata karena kenyataan saja. Aku tidak suka -memperhatikan- niat para pelaku, sekalipun jika ditampakkan akan membuat akad beli menjadi rusak, sebagaimana aku tidak suka terhadap seorang yang membeli pedang untuk membunuh, dan tidak haram pula atas penjual untuk menjual sesuatu yang akan digunakan membunuh secara zhalim. Aku tidak menganggapnya jenis jual beli ini rusak, sebagaimana aku tidak suka seseorang yang menjual anggur kepada orang yang memeras untuk khamar, aku tidak menganggapnya rusak apabila ia menjualnya karena memang anggur itu halal, dan mungkin juga tidak menjadikan sebagai khamar.....Hanya saja aku menganggap rusak akadnya -akad di atas- disebabkan oleh akad yang rusak buat selamanya - bukan karena niat pelaku-.."

Dari penjelasan Imam Syafíi di atas dapat disimpulkan bahwa pelaksanaan Sandak yang dilakukan secara hilah (fiksi hukum), di mana niat para pelaku Sandak untuk mendapatkan keuntungan tidak dipedulikan. Maka cara yang dilakukan adalah benar, karena para pelaku tidak menyebut syarat keharusan menggarap sawah dalam akad. Karena yang terpenting bagi Imam Syafïi adalah persyaratan mengambil manfaat sebagai keuntungan lebih dari pemberian peminjaman tidak disebutkan dalam pangkal akad. Hal ini diperkuat oleh pernyataan ulama Syafi'iyah sebagai berikut: "Menurut pandangan kami riba al-qardl adalah setiap peminjaman yang menarik manfaat

\footnotetext{
${ }^{86}$ al-Syafi'i, al-Umm, jld iii, 65 .
} 
semacam gadai, akan tetapi -hal itu- tidak menjadi haram kecuali persyaratan itu disebutkan dalam pangkal akad." ${ }^{\sharp 7}$

Berbeda halnya bila ditinjau dari hukum al-rahn, maka Imam Syafi’i tidak membolehkannya, sesuai dengan ungkapan beliau: "Manfaat barang gadai adalah milik pemberi gadai, bukan milik penerima gadai sama sekali. ${ }^{88}$ Demikian juga Imam Maliki dan Ahmad bin Hanbal tidak membolehkan pengambilan manfaat seperti yang terjadi dalam Sandak, sebagaimana dijelaskan pada penjelasan yang telah lalu. Kemudian kalau masyarakat Sasak tidak melakukan hilah, maka jelas dua cara yang digunakan oleh masyarakat Sasak dalam melakukan Sandak adalah tepat menurut ulama’ Hanafiyah. Sebab dua cara tersebut diakui oleh ulama Hanafiyah. Dalam hal ini paling tidak dikemukakan argumentasi dari dua cara itu. Pertama. Cara yang pertama, bahwa kebolehan mengambil manfaat oleh penerima gadai apabila ada izin dari pemberi gadai, karena milik yang sah adalah pemberi gadai. Dia bebas memberikan izin kepada siapa yang dikehendaki. Dalam hal ini, terjadinya Sandak adalah dikarenakan adanya izin dari pemberi gadai, dan tidak mungkin tanpa izin. Bahkan orang butuh uang datang kepada pemilik dengan membawa sawah untuk digarap. Hal yang demikian itu merupakan kerelaannya. Hal ini sesuai dengan ungkapan berikut:

“Pada dasarnya penerima gadai tidak berhak atas barang gadaian tanpa ada izin dari pemberi gadai. Adapun bila diberikan izin dan dibolehkan untuk mengambil manfaat, maka bagi penerima gadai boleh menggunakannya dan boleh pula mengambil hasil serta susu -binatangdan hutangnya tidak berkurang sedikitpun karenanya.

Sementara cara yang kedua adalah dengan cara "jual beli sementara” adalah dibenarkan pula menurut ulama Hanafiyah. Dalam hal ini, ulama Hanafiyah memberikan nama dengan istilah "بيع الوفاء”, yaitu jual beli yang diungkapakan oleh penjual (pemberi gadai) kepada pembeli (penerima gadai) dengan ungkapan sebagai berikut: "Sebagai bandingan hutang anda pada saya maka kapan saja anda dapat membayar hutang, barang ini menjadi milik saya”. "Cara seperti ini dikenal dikenal dalam madzhab Hanafi, bahkan pernah diundang-undangkan pada KUHP Islam, yaitu dalam Majallah al-Ahkam al-Adliyah. Di dalamnya diungkapkan tentang

\footnotetext{
${ }^{87}$ al-Dimyathiy, $\underline{\text { Hasyiah, } 20 .}$

${ }^{88}$ al-Syâfi'iy, al-Umm, 155.

${ }^{89}$ Jaudat dkk, Majallah..., 141.

${ }^{90}$ Muhammad Amîn, Qawâ'id al-Fiqh (Karachi: al-Shadaf al-Barkatiy, 1986), 215.
} 
bagaimana penerapan ba'y al-wafa yang sama kedudukannya dengan "jual beli sementara” tersebut. Karena faktor yang ditekankan adalah keterpaksaan untuk memenuhi kebutuhan (penjual untuk mendapat uang), sehingga bentuk jual beli sementara seperti ini adalah boleh. Sebagaimana diungkapkan dalam sebuah kaidah fiqh:

\section{الحاجة تنزل منزلة الضرورة عامة أو خاصة. و من هذا القبيل تجويز البيع \\ بالوفاء حيث إنه لما كثرت الديون على أهل بخارى مست الحاجة إلى ذلك فصسار}

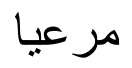

"Kebutuhan itu menempati kemudharatan baik secara umum atau khusus" dari sisi ini ditetapkan kebolehan "ba'y al-wafa" dengan alasan tatakala merajalelanya hutang terhadap penduduk Bukhara', maka hajat sangat butuh kepada "ba’y al-wafa”, sehingga dipelihara (dibolehkan)."91

Tegasnya terjadinya cara jual beli ini adalah dikarenakan kebutuhan (hajat) yang mendesak untuk mengatasi masalah yang dihadapi sebagaimana yang diungkapkan:

$$
\text { بيع الوفاء إنه صحيح لحاجة الناس فرارا من الربا }
$$

“Bay’ al-wafa'itu boleh/sah karena kebutuhan orang untuk menghindari riba”. ${ }^{92}$

Untuk memberikan kejelasan masing-masing perspektif, penulis menampilkan dalam betuk tabel sebagai berikut:

Tabel 1.1 Perspektif Penulis Hukum Sandak

\begin{tabular}{|c|c|c|c|}
\hline No: & Perspektif & Hukum Sandak & Alasan \\
\hline 1. & Al-Qardl & a. Tidak boleh & $\begin{array}{l}\text { Karena dalam pemberian pinjaman } \\
\text { pemberi pinjaman memberikan } \\
\text { pinjaman untuk mendapatkan } \\
\text { penggarapan sawah, sehingga } \\
\text { menjadi kelebihan yang identik } \\
\text { dengan riba dalam pemberian } \\
\text { pinjman, sesuai dengan qaidah } \\
\text { fiqhiyah: Qullu qardl jarra } \\
\text { manfatan fahuwa riba" } \\
\text { Menurut sebagian ulama' selama } \\
\text { dalam aqad suatu pinjaman tidak } \\
\text { disebutkan adanya kelebihan } \\
\text { pengembalian, maka yang demikian } \\
\text { itu boleh dilakukan. (Cara ini sulit } \\
\text { terjadi, sebab otomatis dilakukan } \\
\text { pemilik sawah dengan serta merta } \\
\text { menverahkan sawah tampa ada }\end{array}$ \\
\hline
\end{tabular}

\footnotetext{
${ }^{91}$ Jaudat dkk, Majallah...., 19.

${ }^{92} \mathrm{Ibnu}$ 'Âbidîn, al-Dlurar al-Mukhtar (Beirut: ttp, 1386H), jld v, 297.
} 


\begin{tabular}{|c|c|c|c|}
\hline & & & penyebutan dalam aqad) \\
\hline 2. & al-Rahn & $\begin{array}{l}\text { a. Tidak Boleh } \\
\text { b. Boleh }\end{array}$ & $\begin{array}{l}\text { Menurut mazhab Maliki, Syafi'i } \\
\text { dan Hambali yang berhak } \\
\text { menggunakan barang gadai adalah } \\
\text { pemberi gadai, sementara penerima } \\
\text { gadai hanya memegang barang } \\
\text { jaminan. } \\
\text { Menurut mazhab Hanafi } \\
\text { pengambilan manfaat Sawah } \\
\text { gadaian dibolehkan selama ada } \\
\text { izin dari pemilik sawah. }\end{array}$ \\
\hline 3. & Riba & a. Tidak Boleh & $\begin{array}{l}\text { Karena pengambilan manfaat yang } \\
\text { diambil oleh penerima gadai adalah } \\
\text { sama dengan peminjaman yang } \\
\text { ditimbulkan akibat peminjaman (al- } \\
\text { Qardl), karena itu Sandak sama } \\
\text { dengan riba al-Qardl. }\end{array}$ \\
\hline 4 & $\begin{array}{l}\text { Ba'i al- } \\
\text { Wafa' }\end{array}$ & b. Boleh & $\begin{array}{l}\text { Karena, kesulitan yang dirasakan } \\
\text { untuk mendapat pinjaman } \\
\text { menjadikan sesuatu yang bersifat } \\
\text { "kebutuhan" menjadi sama halnya } \\
\text { dengan darurat. Hal ini yang } \\
\text { diterapkan oleh KUHP pada masa } \\
\text { Turki Usmani dengan cara "ba'i al- } \\
\text { Wafa' (jual beli sementara) }\end{array}$ \\
\hline
\end{tabular}

\section{Kesimpulan}

Masyarakat Sasak melakukan praktek Sandak dikarenakan oleh kebutuhan yang mendesak, baik berupa kebutuhan konsumtif atau produktif.Sementara implikasi pelakasanan Sandak dalam masyarakat Sasak adalah negatif dan positif. Negatifnya bagi penerima pinjaman adalah bila ia tidak bisa menggunakan pinjaman, maka ia akan mendapatkan kesulitan yang cukup lama, karena sawah/kebun yang digadaikan tetap berada pada tangan pemberi panjaman. Sementara positifnya bagi penerima pinjaman dapat lolos dari kesulitan. Hukum Sandak dalam teori al-qardl, al-rahn dan al-riba adalah bervariasi sesuai dengan akadnya, sehingga bisa menjadi boleh atau tidak boleh. Tapi dalam pelaksanannya masyarakat Sasak adalah mengikuti pandangan Hanafiyah yang membolehkan dengan jalan izin dan jual beli sementar (ba'y al-wafa). Dari itu sesungguhnya masyarakat Sasak yang dikatakan pengikut setia madzhab Syafi'i, tetapi sebenarnya secara tidak "sadar" telah mengikuti pandangan madzhab Hanafi. Walllu 'Alam• 


\section{Daftar Pustaka}

-------, Musnad al-Syâfïiy (Bairut: Dâr al-Kutub al-Ilmiyah tt.).

'Abidîn, Ibnu, al-Dlurar al-Mukhtar (Bairut: ttp, 1386 H).

al-Anshariy, Abi Zakariya, Fath al-Wahhâb bi Syarh Minhaj al-Thâlibîn (Semarang: Maktabah wa Mathba'ah Toha Putra, tt).

al-Bagdhadi, Abdul Wahhab, al-Mu’awwanah al-Imâm Mâlik bin Anas (Bairut: Dâr al-Fikr, 1995).

al-Bajuriy, Syarh al-Bajuriy (Bairut: Dâr al-Fikr, tt).

al-Bantaniy, al-Nawawi, Nihâyah al-Zain fî Irsyâd al-Mubtadi’̂̀n (Bandung: Syirkah al-Ma'arif li al-Thaba; wa al-Nasyar, tt).

al-Bukhariy, Muhammad Ismâ'îl Abu Abdillah, al-Jami’ al-Shahîh $\underline{h}$ al-Mukhtashar, (Beirut: Dâr Ibnu Kasitm 1989).

al-Daruquthniy, Sunan al-Daruquthniy (Beirut: Dâr al-Ma'rifah, 1966).

al-Dimyathiy, Muhammad Syatha', 'I’ânah al-Thâlibîn (Semarang: Maktabah wa Mathba'ah Toha Putra, tt).

al-Jashash, Abu Bakar, al-Ahkkam al-Qur'ân (Bairut: Dâr al-Fikr, 1996).

al-Jaziriy, Abdurrahman, al-Fiqh 'alâ Madzâhib al-'Arba’ah (Bairut: Dâr al-Qalam, tt).

al-Jurjaniy, Ali bin Muhammad bin Ali, al-Ta'rifat (Beirut: Dâr al-Kitab al-Arabiy, 1305 H).

al-Khin, Musthafa dkk., Al-Fiqh al-Minhaj 'alâ Madzhab al-Imâm al-Syâfi'iy (Dimasq: Dar alQalam, 1992).

al-Muqaddasi, Ibnu Qudamah, al-Kâfî fî Fiqh al-Imâm al-Mujabbal Ahmad bin Hanbal, (Beirut: al-Maktabah al-Islamiy, 1988).

al-Muzanniy, Mukhtashar al-Muzanniy 'alâ al-Imâm Muhammad bin Idrîs al-Syâfỉ'iy, (Beirut: Dâr al-Kutub al-Ilmiyah, 1993).

al-Shan'niy, Subl al-Salâm Syarh Bulûgh al-Marâm (Makkah: Jami’ah al-Imâm Muhammad bin Su'ud al-Islamiyah, 1408H).

al-Suyuthiy, Jalâl al-Dîn, al-Ashbah al-Nazhẩir (Beirut: Dâr al-Fikr, tt).

al-Syâfi'iy, Muhammad bin Idrîs, al-Umm (Beirut: Dâr al-Ma'rifah, 1393 H).

al-Syarwaniy, Abdul Hâmid, al-Syarwaniy 'alâ Tuhfah al-Minhaj bi Syarh al-Minhaj (Beirut: Dâr al-Fikr, tt).

al-Syaukaniy, Muhammad bin Ali, al-Sail al-Jarar al-Mutadaffiq 'alâ Hadâ’iq al-Azhar (Beirut: Dâr al-Kutubal-Ilmiyah,tt).

al-Syawi, Syaikh Ahmad, Bulghah al-Sâlik lî Aqrab al-Masâlik (Beirut: Dâr al-Fikr, tt).

al-Zuhaili, Wahbah, al-Fiqh al-Islâmiy wa Adillatuh (Beirut: Dâr al-Fikr, 1989).

Amîn, Muhammad, Qawẩid al-Fiqh (Karachi: al-Shadaf al-Barkatiy, 1986).

Antonio, Muhammad Syafi'i, Bank Syariah Dari Teori ke Praktek (Jakarta: Gema Insani Press, 2001). 
Asnawi, "Solidaritas Sosial Masyarakat Dalam Pembangunan Suatu Kajian Sosial Kultural Religius Pada Masyarakat Sasak", laporan penelitian (tidak diterbitkan, STAIN Mataram, 1997.

Atwi, Fauzi, al-Iqtishâd wa al-Mâl fî̀ al-Tasyrî̀ al-Islâmiy wa al-Nuzhûm al-Wadl iyyah (Beirut: Dâr al-Fikr al-Arabiy, 1988).

Hajawi, Ahmad, al-Raudl al-Murabba' bi Syarh Zad al-Mustqna’ Mukhtashar al-Muqna’ (Beirut: Dâr al-Kutub al-Ilmiyah, 1988).

Hazm, Ibnu, al-Muhalla (Beirut: Dâr al-Fikr, tt.)

Jarîr, Ibnu, Tafsir Ibnu Jarîr (Bairut: Dâr al-Qalam, 1987)

Jaudat, Ahmad dkk, Majallah al-Ahkam al-Adliyah (Ttp.t.p, 1968).

Khalaf, Abdul Wahhab, Ilm Ushûl Fiqh (Beirut: Dâr al-Qalam, 1978).

Maududiy, Abu 'Ala, al-Ribâ (Beirut: Dâr al-Fikr, tt).

Minhaji, Akh., Ahmad Hasan and Islamic Reform (1887-1958) (Yogyakarta: Kurnia Kalam Semesta Press, 2000).

Moleong, Lexy J., Metodelogi Penelitian Kualitatif (Bandung: Remaja Rosdakarya, 2000).

Mudzhar, Atha', Studi Hukum Islam dengan Pendeketan Sosilogi (Yogyakarta: IAIN Sunan Kalijaga, 1999).

Muhajir, Noeng, Metodelogi Penelitian Kualitatif(Yogyakarta: Rake Sarasin, 2000).

Nabhan, Muhammad Farûq, al-Ittijah al-Jama'iy fî̀ al-Tasyrî’ al-Iqtishâdiy al-Islâmiy (Beirut: Mu'assah al-Risalah, 1984).

Nawawi, Haidar, Metode Penelitian Bidang Sosial (Yogyakarta: Gajah Mada University Press, 1995).

Nawawi, Muhyiddîn, al-Majmu’ Syarh al-Muhadzdzab (Beirut: Dâr al-Fikr, tt).

Reyner, S.E., The Theory of Contracts in Islmic Law (London: Graham dan Trotman, 1991).

Rusyd, Ibnu, Bidâyah al-Mujtahid wa Nihâyah al-Muqtashid (Semarang: Maktabah Wa Mathba'ah Toha Putra, tt)

Sabiq, Sayyid, Fiqh al-Sunnah (Beirut: Dâr al-Kutub al-Arabiy, 1985).

Siddiqi, Najtullah, Kemitraan Usaha dan Bagi Hasil Dalam Hukum Islam (Jakarta: Dana Bhakti Prima Yasam tt).

Singaribuan, Masri dan Sofian Efendi, Metode Penelitian Survai (Jakarta: LP3S Indonesia, 1995).

Suhartono, Irwan, Metode Penelitian Sosial (Jakarta: Remaja Rosdakarya, 1998).

Suryabrata, Sumardi, Metode Penelitian (Jakarta: Raja Grafindo, 1998)

Syaltût, Muhammad, al-Fatawâ (Beirut: Dâr al-Qalam, tt).

Zakariya, Abi, Raudlah al-Thâlibîn wa Umdah al-Muftîn (Bairut: Dâr al-Fikr, 1995). 